\title{
Structure Analysis of an RNA Aptamer Binding to a Stem-loop RNA
}

\author{
Bongrae Cho \\ Department of Applied Chemistr. Cheongin University. Cheongiu $360-764$. Korea E-mail: brchoiácjuack \\ Received Februarv 22. 2008
}

Key Words : RNase T1. RNase S1. RNase V1, RNA aptamer, Stem-loop RNA

RNA structure can be analyzzed by biophỵsical or biochemical methods. X-ray crystallography or NMR (nuclear magnetic resonance) involved in biophysical method has not been popular so far because it is not easy to make RNA crystal for X-ray cry stallography and the small size of RNA only is available for the structural analysis with NMR. ${ }^{l}$ So biochemical methods using structure specific enzymes and chemicals have been used widely Enzymes and chemical which have been used for probing RNA structure in solution. are double-strand-specific RNase V1, single-strand-specific nuclease S1. RNase T1 which has a specificity for a guanine in single strand region, and kethoxal (3-ethoxy-1.1-dihydroxy-2-butanone). which modify the N1 and N2 of guanine in the single strand. Hydroxyl radical $(\mathrm{OH})$ has also been used for the structural analy sis of RNA. Exposed nucleotides are damaged by hydroxyl radical while nucleotides involved in tertiary contacts are protected from damage. making it a favorable approach for establishing exterior/interior relations for RNA. ${ }^{6-12}$ Radicals are generated from Fe(II)-EDTA with hydrogen peroxide $\left(\mathrm{H}_{2} \mathrm{O}_{2}\right)$. Ascorbate (or DTT) is added to reduce $\mathrm{Fe}(\mathrm{III})$ to $\mathrm{Fe}(\mathrm{II})$. Hydrogen abstraction from the ribose 4' carbon leads to strand scission. Enzymes whose size is above $100 \mathrm{~A}$. may have an accessibility problem to target RNA because of their big size. To overcome this problem. sometimes radical or chemicals whose size is below $10 \mathrm{~A}$ can be used.

RNA aptamers which bind to a stem-loop RNA. which plays an important role in the synthesis of gag-pol fusion protein in HIV-1 were selected from a random-sequence RNA library. ${ }^{13}$ In this work. the structure of the RNA aptamer 13-1-3, one of the selected RNA aptamers was found by the MFOLD program accessed on the intemet (www.bioinfo.rpi.edu/applications/mfold/old/ma) and also supported by RNA structural probes such as RNase $\mathrm{Tl}$. RNase V1 and nuclease S1.

The structure of RNA aptamer 13-1-3 was probed in binding buffer with RNase T1, RNase V1, and nuclease S1 (Fig. 1). G13, Gl4, G15, and G28 were cleaved by RNase
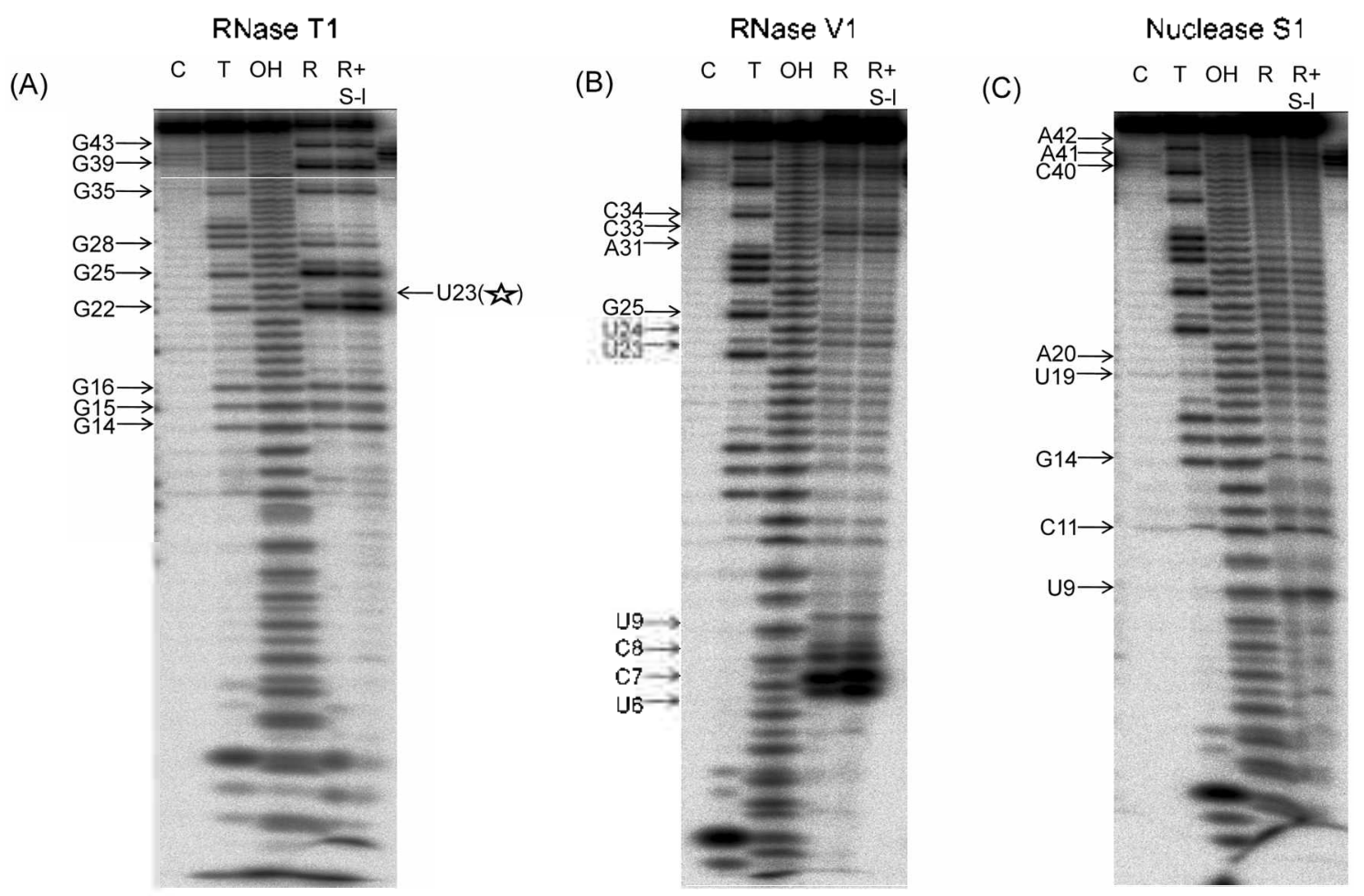

Figure 1. Enzymatic probing of RNA aptamer 13-1-3 labeled at the 5'-end. The RNA was partially digested with RNase Tl (A), RNase VI (B) and nuclease S1 (C). The cleaved nucleotides are indicated by arrows. Residue U23 protected trom RNase Tl digestion by stem-loop RNA was marked with a star. Lane C, control: lane T, the denatured RNA treated with RNase T1; lane OH, partial alkalune ladder. lanes R and $R+S-1$, enzymatic cleavages in the absence of and the presence of stem-loop RNA, respectively. 


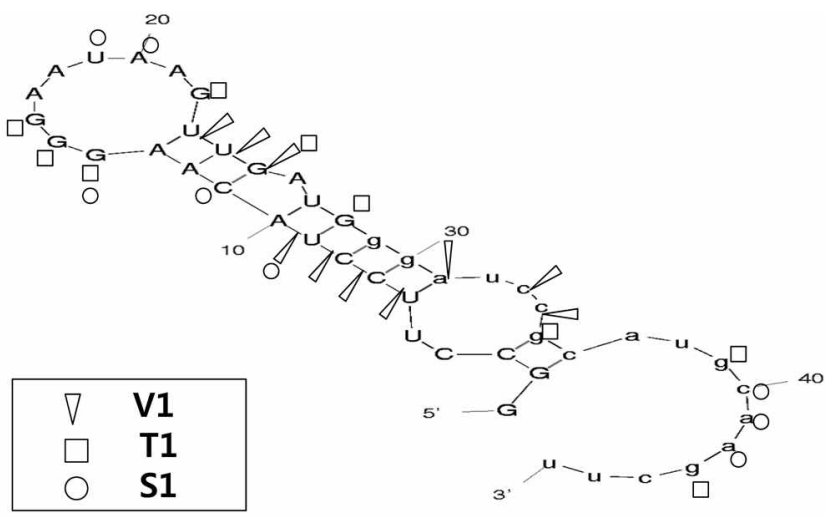

Figure 2. Schematic representation of possible secondary structure of RNA aptamer 13-1-3. Triangles indicate the sites cleaved by $\mathrm{RNase} \mathrm{VI}$, squares indicate the sites cleaved by RNase $\mathrm{Tl}$ and circles indicate the sites cleaved by nuclease $\mathrm{Sl}$.

$\mathrm{T} 1$, especially strong cleavages at $\mathrm{G} 20, \mathrm{G} 25 . \mathrm{G} 35 . \mathrm{G} 39$ and G43. so these guanines are thought to be in single-strand region of the secondary structure model of RNA aptamer 13. 1-3. Residue U23 marked with a star, was protected from RNase Tl digestion by the stem-loop RNA. a ligand used for selection of this RNA aptamer 13-1-3. Footprinting studies are in progress to evaluate which sequence of RNA aptamer 13-1-3 is important for the interaction between the RNA aptamer and the stem-loop RNA ligand. and will be discussed later.

Regions U23UG25 and A31 were cleaved by RNase VI. especially strong cleavages at region U6CCU9 and so these regions are thought to be located in double strand. But the region $\mathrm{C} 33 \mathrm{C} 34$ which was thought to be in single strand. was susceptible to RNase VI. suggesting that this region was stacked from intramolecular interaction and became accessible to $\mathrm{RNase} \mathrm{V} 1$ in solution.

Residues U9, C11, G14, U19A20 and C40AA42 were cleaved by nuclease $S 1$, so these regions are thought to be in single-strand region of the secondary structure model of RNA aptamer 13-1-3. The residue C11 was susceptible to nuclease $\mathrm{S} 1$ and residue $\mathrm{G} 25$ was attacked by both RNase $\mathrm{T} 1$ and RNase V1 and so C11:G25 base pair is thought to be unstable because of the adjacent presence of a bulge A26.

In conclusion. the structure of RNA aptamer 13-1-3 was analyzed in solution with probes such as RNase Tl. RNase $\mathrm{V} 1$, and nuclease $\mathrm{S} 1$ and its possible secondary structure was represented (Fig. 2). The result suggested that 1) this molecule has three single strand regions and two double strand regions. a long double strand region of the two has a bulge A26. and 2) C11:G25 base pair is unstable because of the adjacent presence of a bulge A26.

\section{Experimental Section}

Preparation of RNA. RNA aptamer 13-1-3 was synthesized by run-off in vitro transcription with T7 RNA polymerase from the DNA template to which the T7 promoter was annealed and purified by gel elution of the crush and soak method. ${ }^{1+}$ The resulting RNA was treated with CIP (calf intestinal alkaline phosphatase) to remove 5 ' end phosphate and then labeled at the $5^{\prime}$ end using $\left[\gamma^{2}{ }^{32}\right.$ P]ATP and $\mathrm{T} 4$ polynucleotide kinase.

Enzymatic Cleavage Reaction. 5'-terminal radiolabeled RNA aptamer $13.1-3$ was heated in binding buffer $(30 \mathrm{mM}$ Tris-acetate, $\mathrm{pH} 7.5,60 \mathrm{mM}$ magnesium acetate, $120 \mathrm{mM}$ potassium acetate. and $120 \mathrm{mM}$ ammonium acetate) at $70^{\circ} \mathrm{C}$ for $5 \mathrm{~min}$ and allowed to cool to RT $\left(-21^{\circ} \mathrm{C}\right)$. Then $0.1-1$ unit of nuclease SI (Boehringer Manheim $\mathrm{GmbH}$. W. Germany) or 0.001-0.01 unit of RNase Vl (Pierce Molecular Biology, Perbio) or 0.1-1 unit of RNase Tl (Industrial Research Limited) was added to the above mixture and then the reaction mixture was incubated for $20 \mathrm{~min}$ at RT. The reaction volume included an additional $1 \mathrm{mM} \mathrm{ZnCl}$. for nuclease $S$ I cleavage. The cleavage products were recovered by ethanol precipitation and separated on a $15 \%$ polyacylamide gel in $90 \mathrm{mM}$ Tris-borate $(\mathrm{pH} 8.3$ ) and $2.5 \mathrm{mM}$ EDTA containing $7 \mathrm{M}$ urea.

Acknowledgements. I appreciate Prof. Younghoon Lee (Department of Chemistry and Center for Molecular Design and Synthesis. Korea Advanced Institute of Science and Technology) for his helpful discussion.

\section{References}

1. Lee. J.-H. Bull. Konan Chem. Soc. 2007. 28.1643.

2. Ko. J.-H.: Cho, B; Ahn, J. K; Lee. Y; Park, I. Bull. Komen Chem. Soc. 1999, 20. 1335.

3. Brunel. C.: Romby. P. Hethods in Enzznology 2000. 318.3.

4. Ko. J: Lee. Y: Park. I.: Cho. B. FEBS Lett. 2001. 508.300.

5. Cho. B. Bull. Korean Chem. Soc. 2006. 27. 786.

6. Latham. J.: Cech. T. Science 1989, 45. 276.

7. Stern, S.: Moazed, D.: Noller, H. Methods Enzynol 1988. 164. 481

8. Murphy. F. L.: Cech. T. R. Biochemistry 1993.32.5291.

9. Rangan1. P.: Masquida. B.: Westhof. E.: Woodson. S. Proc. Notl. Acad. Sci. USA 2003. 100. 1574

10. Tsar, H.: Masjunda. B.; Biswas. R.: Westhof. E.; Gopalan, V. $f$. 1. fol. Biol. 2003, 325.661

11. Barrera, A.: Pan. T. $R$ NA 2004, 10,482.

12. Bergman. N.: Lau. N.: Lehnert. V.: Westhof. E.: Bartel. D. P. RV. 2004. 10. 176

13. Shit1. E.-S.: Lee. Y.: Cho. B. FEBS Lett. 2008. submitted.

14. Sambrook. J.: Fritsch, E. F.: Maniatis, T. Holecular Clong: At Laboratory Mammal, 2nd ed.: Cold Spring Harbor Laboratory Press: Cold Spring Harbor, NY. 1989. 